\title{
Brief communication: Two well-marked cases of aerodynamic adjustment of sastrugi
}

\author{
C. Amory ${ }^{1,2,3}$, F. Naaim-Bouvet ${ }^{3}$, H. Gallée ${ }^{1,2}$, and E. Vignon ${ }^{1,2}$ \\ ${ }^{1}$ Univ. Grenoble Alpes, LGGE, 38041 Grenoble, France \\ ${ }^{2}$ CNRS, LGGE, UMR5183, 38401 Grenoble, France \\ ${ }^{3}$ Univ. Grenoble Alpes, IRSTEA, UR ETNA, 38042 St-Martin-d'Hères, France \\ Correspondence to: C. Amory (amory@lgge.obs.ujf-grenoble.fr)
}

Received: 14 October 2015 - Published in The Cryosphere Discuss.: 2 November 2015

Revised: 16 March 2016 - Accepted: 17 March 2016 - Published: 1 April 2016

\begin{abstract}
In polar regions, sastrugi are a direct manifestation of drifting snow and form the main surface roughness elements. In turn, sastrugi alter the generation of atmospheric turbulence and thus modify the wind field and the aeolian snow mass fluxes. Little attention has been paid to these feedback processes, mainly because of experimental difficulties. As a result, most polar atmospheric models currently ignore sastrugi over snow-covered regions. This paper aims at quantifying the potential influence of sastrugi on the local wind field and on snow erosion over a sastrugi-covered snowfield in coastal Adélie Land, East Antarctica. We focus on two erosion events during which sastrugi responses to shifts in wind direction have been interpreted from temporal variations in drag and aeolian snow mass flux measurements during austral winter 2013. Using this data set, it is shown that (i) neutral stability, $10 \mathrm{~m}$ drag coefficient $\left(C_{\mathrm{DN} 10}\right)$ values are in the range of $1.3-1.5 \times 10^{-3}$ when the wind is well aligned with the sastrugi, (ii) as the wind shifts by only 20 $30^{\circ}$ away from the streamlined direction, $C_{\mathrm{DN} 10}$ increases (by 30-120\%) and the aeolian snow mass flux decreases (by $30-80 \%$ ), thereby reflecting the growing contribution of the sastrugi form drag to the total surface drag and its inhibiting effect on snow erosion, (iii) the timescale of sastrugi aerodynamic adjustment can be as short as $3 \mathrm{~h}$ for friction velocities greater than $1 \mathrm{~m} \mathrm{~s}^{-1}$ and during strong drifting snow conditions and (iv) knowing $C_{\mathrm{DN} 10}$ is not sufficient to estimate the snow erosion flux that results from drag partitioning at the surface because $C_{\mathrm{DN} 10}$ includes the contribution of the sastrugi form drag.
\end{abstract}

\section{Introduction}

In polar regions, sastrugi are a direct manifestation of drifting snow. They are generally regarded as elongated ridges of wind-packed snow 1 to $2 \mathrm{~m}$ in length, with a longitudinal axis parallel to the prevailing wind at the time of their formation. These erosional surface roughness features are very widespread over the Antarctic ice sheet (Kotlyakov, 1961), where they can be major determinants of surface roughness (Jackson and Carroll, 1978; Inoue, 1989; Andreas and Claffey, 1995). Sastrugi orientations have been recognized as useful indicators of the Antarctic near-surface wind direction (Mather, 1962, 1969; Mather and Miller, 1966; Long and Drinkwater, 2000) in agreement with continent-scale modelling studies (Parish and Bromwich, 1987, 2007).

The development of sastrugi depends on the ability of snow to be eroded and thus on the threshold velocity needed to lift snow particles from the surface. In the literature, aeolian erosion thresholds have been reported to vary depending on temperature and diverse properties of surface snow. From observations in Antarctica, Mellor (1965) reported that $10 \mathrm{~m}$ wind speeds of 3 to $8 \mathrm{~m} \mathrm{~s}^{-1}$ are strong enough to cause aerodynamic entrainment of loose, unbounded snow, whereas winds exceeding $30 \mathrm{~m} \mathrm{~s}^{-1}$ are needed to erode snow consolidated by the freeze-thaw process. Budd et al. (1966) suggested a high threshold wind speed $\left(14 \mathrm{~m} \mathrm{~s}^{-1}\right)$ was needed to trigger snow transport in the cold environment of Byrd station. Schmidt (1980) reported that the cohesion of the snow surface determines the threshold speed required for snow erosion to occur. Schmidt (1980) also showed that the threshold wind speed increases with time since snow depo- 
sition and that this increase slows with time and is slower at lower temperatures. Pomeroy et al. (1993) identified significantly lower thresholds for fresh, loose, dry snow than for older, wind hardened, dense or wet snow. Oura et al. (1967) and, later on, Li and Pomeroy (1997) discussed the major role of temperature in surface erodibility (i.e. the potential of a surface to be eroded; Shao, 2008) through metamorphism of snow (i.e. changes in snow structure over time), and showed an empirical but generally positive correlation between threshold wind speed and air temperature. All studies suggest that the physical properties of the snow play a major role in the formation of sastrugi.

Sastrugi contribute to the drag exerted on the atmosphere over the snow surface and enhance interactions at the airsnow interface compared to a smooth snow surface. Rougher snow surfaces favour the generation of turbulence in the nearsurface air stream that is likely to further increase the aeolian snow mass flux (Das et al., 2013). On the other hand, sastrugi are responsible for a loss of wind momentum through pressure fluctuation gradients in their immediate vicinity (sastrugi form drag) that directly reduces the energy budget available for erosion of snow. Little attention has been paid to these feedback processes, mainly because of experimental difficulties. As a result, most polar atmospheric models ignore sastrugi over snow-covered regions. The attenuating effect on snow erosion is taken into account in the coupled atmosphere/snowpack/aeolian snow transport model MAR (Gallée et al., 2013) and is currently parameterized as in Marticorena and Bergametti (1995) for non-erodible roughness elements. By comparing observed and simulated aeolian snow mass fluxes over Adélie Land using MAR, Amory et al. (2015) showed that in the model, erosion efficiency is highly sensitive to the parameterization of surface roughness, and underlined the need for observational characterization of interactions between wind-induced roughness features and aeolian transport of snow.

Some authors have shown that the sastrugi form drag actually depends on how the wind is oriented with respect to the main sastrugi axis. Based on measurements of wind speed and temperature profile in the atmospheric surface layer at the South Pole, Jackson and Carroll (1978) reported that sastrugi form drag was essentially absent when the wind was perfectly aligned with the sastrugi up to a height of $50 \mathrm{~cm}$. As the wind rotated, sastrugi form drag increased to reach maximum when the wind direction was perpendicular to the prior sastrugi pattern. These authors developed an idealized single sastruga model from Lettau's (1969) findings to reproduce their observations. Using another analytical sastruga model adapted from Raupach (1992), Andreas (1995) also found a minimum and a maximum drag for wind directions respectively parallel and perpendicular to the sastruga longitudinal axis. However, these modelling efforts were undertaken without accounting for the erodible character of sastrugi or for their possible reorganization when realigning with persistent (erosive) winds blowing transversally to their elongated sidewalls. If the crosswise flow continues from a relatively constant direction while allowing sufficient shear stress to dislodge snow surface particles, sastrugi can adjust aerodynamically; transversal sastrugi are eroded and new streamlined sastrugi form parallel to the mean wind (Andreas and Claffey, 1995). This results in a gradual decrease in the contribution of the sastrugi to the total surface drag and hence in an increase in erosion efficiency. Andreas and Claffey (1995) reported that the timescale for this streamlining process on Weddell Sea ice in winter was about half a day with 6$8 \mathrm{~m} \mathrm{~s}^{-1}$ winds, but might be shorter if the winds are stronger. To date, no observational study has provided quantitative insight into the potential effect of erodible roughness elements of the snow surface on snow erosion.

Quantifying the variable influence of sastrugi on the local wind field and associated surface drag could improve parameterization of surface roughness and erosion in polar atmospheric models that currently ignore sastrugi. The present paper focuses on two erosion events during which sastrugi responses to shifts in wind direction have been interpreted from temporal variations in drag and aeolian snow mass flux measurements in coastal Adélie Land during austral winter 2013.

\section{Data and method}

\subsection{Field area}

Site D17 $\left(66.7^{\circ} \mathrm{S}, 139.9^{\circ} \mathrm{E}\right.$; $450 \mathrm{~m}$ a.s.1.) is located about $10 \mathrm{~km}$ inland in a coastal accumulation zone of Adélie Land (Agosta et al., 2012), roughly $15 \mathrm{~km}$ south-west of the permanent French station Dumont d'Urville (Fig. 1). An annual temperature of $-10.8^{\circ} \mathrm{C}$ and a mean wind of around $10 \mathrm{~m} \mathrm{~s}^{-1}$ have been reported at Dumont d'Urville station (König-Langlo et al., 1998). The measurement area consists of a gently sloping snowfield with a long unobstructed upstream fetch extending over several hundreds of kilometres inland over a uniform snow surface. Local topographic channelling acts together with the Coriolis force to produce southeasterly flows all year round that result either from pure katabatic or combined katabatic-synoptic forcings (Parish et al., 1993).

Site D17 is visited only during summer (December to February), when the presence of sastrugi is often reported. Frequent strong winds combined with the permanent snow surface lead to frequent aeolian snow transport events (Trouvilliez et al., 2014), thereby favouring aerodynamic adjustment of the snow surface. This results in a net south-southeast orientation of the sastrugi (Fig. 2).

\subsection{Instrumentation}

The measurement structure deployed at site D17 is a $7 \mathrm{~m}$ high meteorological mast. Wind speed, relative humidity and air temperature are recorded along the mast at six log- 


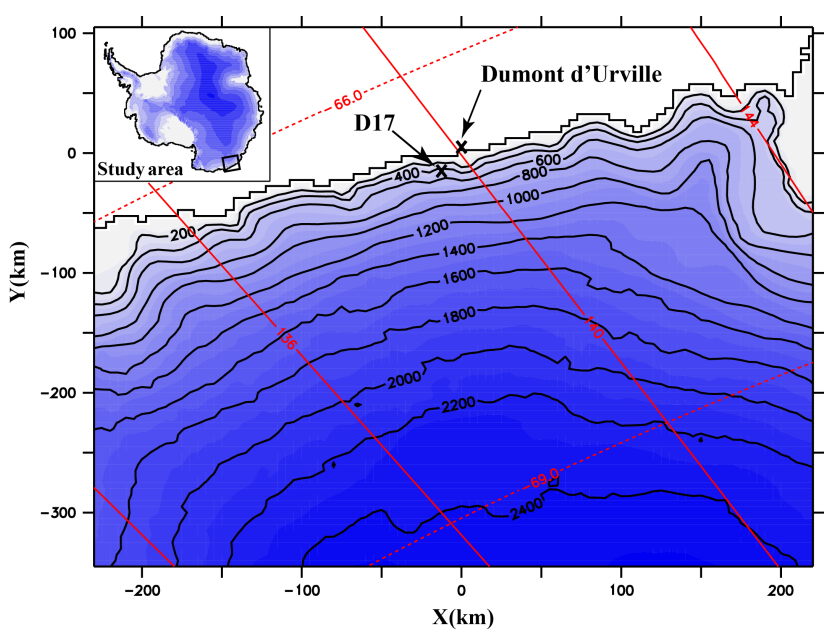

Figure 1. Map of Adélie Land showing the location of Dumont d'Urville station and measurement site D17. Contour lines are in meters.

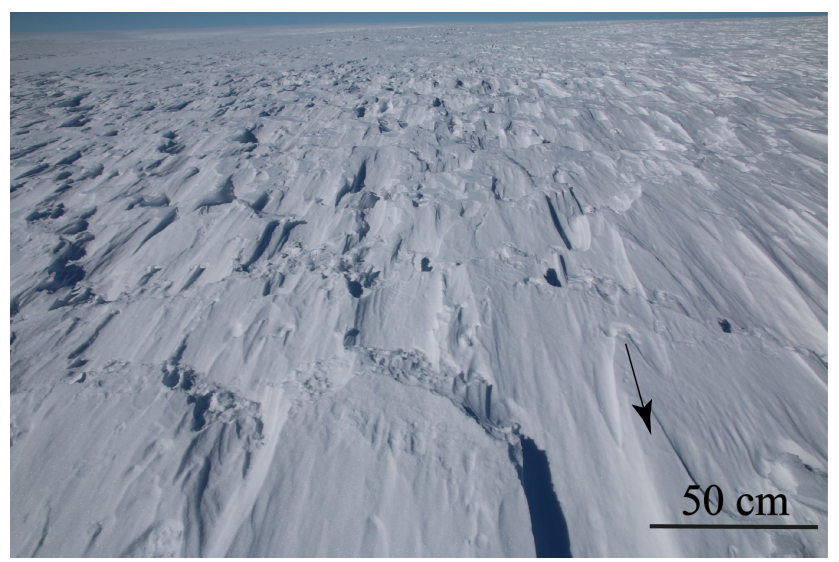

Figure 2. Photograph of the snow surface at D17 in January 2014. The arrow indicates the mean direction of the wind episode that led to the formation of the sastrugi.

arithmically spaced intervals between 0.8 and $7 \mathrm{~m}$ above the snow surface using Vector A100LK cup anemometers and HMP45A thermo-hygrometers installed in naturally ventilated MET21 radiation shields. The anemometers are mounted on roughly $1 \mathrm{~m}$ long booms pointing southeastward. Wind direction is only sampled at the upper level by a Vector W200P wind vane. Surface level variations are measured by a Campbell SR50A acoustic depth gauge. Information on drifting snow is obtained from a secondgeneration acoustic FlowCapt ${ }^{\mathrm{TM}}$ device that was set up vertically close to the ground to allow detection of the beginning of aeolian snow transport events. The sensor is a $1 \mathrm{~m}$ long tube that converts the acoustic pressure caused by snow particles impacting the tube into an aeolian snow mass flux integrated over the length of the tube. The second-generation FlowCapt ${ }^{\mathrm{TM}}$ was evaluated in the French Alps by Trouvil- liez et al. (2015). They reported that the instrument underestimates the aeolian snow mass flux compared to a reference optical sensor (snow particle counter S7; Sato et al., 1993), especially during snowfalls. Nevertheless, the equivocal behaviour of the second-generation FlowCapt ${ }^{\mathrm{TM}}$ does not affect its ability to accurately detect the occurrence of aeolian snow transport. Data were sampled at $15 \mathrm{~s}$ intervals, averaged to half-hourly means and stored in a Campbell CR3000 datalogger.

\subsection{The $10 \mathrm{~m}$ drag coefficient in near-neutral conditions}

Computing the drag coefficient $\left(C_{\mathrm{D}}\right)$ is a convenient way to estimate the local drag exerted by the surface on the overlying air. $C_{\mathrm{D}}$ can be computed by measuring the vertical wind speed gradient (profile method) under near-neutral conditions following the Monin-Obukhov similarity theory. Assuming stationarity and horizontal homogeneity when the atmospheric surface layer is statically neutral, the wind speed profile is logarithmic:

$U(z)=\frac{u_{*}}{\kappa} \ln \left(\frac{z}{z_{0}}\right)$,

where $U(z)$ is the average wind speed as a function of height $z, \kappa$ is the von Kármán constant (taken as 0.4 ), $z_{0}$ is the aerodynamic roughness length and $u_{*}$ the friction velocity describing the wind shear at the surface, related to the vertical momentum flux at the surface ( $\tau$; also known as Reynolds shear stress):

$\tau=\rho u_{*}^{2}=-\rho \bar{u} \bar{w}=\rho C_{\mathrm{DN} z} U_{z}^{2}$,

where $\rho$ is the air density, $u$ and $w$ are fluctuations in the longitudinal and vertical turbulent velocity, and $C_{\mathrm{DN} z}$ and $U_{z}$ are the neutral-stability drag coefficient and the average wind speed at height $z$. The overbar stands for a time average. $C_{\mathrm{DN}}$ is usually discussed at a standard reference height of $10 \mathrm{~m}$ $\left(C_{\mathrm{DN} 10}\right)$. From Eqs. (2) and (3), we deduce the following:

$C_{\mathrm{DN} 10}=\left[\kappa / \ln \left(\frac{10}{z_{0}}\right)\right]^{2}$,

with $z_{0}$ expressed in metres. Here $C_{\mathrm{DN} 10}$ and $z_{0}$ are two equivalent quantities for evaluating the momentum exchange at the air-snow interface that results from the integrated (in space and time) turbulent drag caused by the roughness elements.

The wind profiles used to compute $C_{\mathrm{DN} 10}$ were selected following a strict procedure. After discarding icing or malfunctioning cases and half-hourly runs for which a rare (north-westerly) flow was likely to be disturbed by the measurement structure, stationary conditions were selected by requiring that temperature changes between two consecutive half-hourly runs should not exceed $0.3 \mathrm{~K}$, following Joffre (1982)'s recommendations. Near-neutral conditions were 

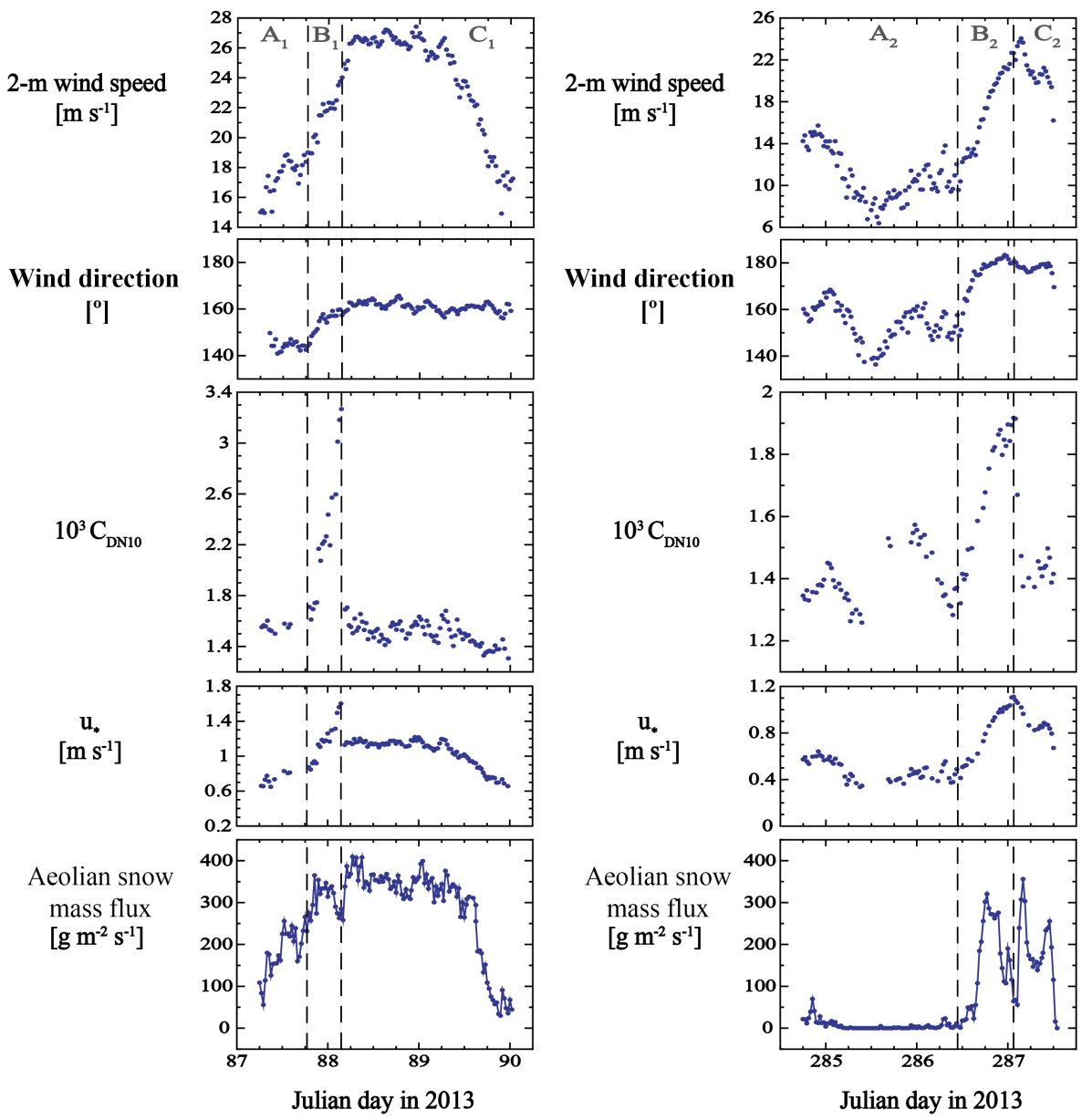

Figure 3. Two erosion events showing sastrugi responses to shifts in wind direction. Note the different vertical scales between right and left panels concerning measured $2 \mathrm{~m}$ wind speed, profile-derived $C_{\mathrm{DN} 10}$ and $u_{*}$ values. In both cases, the event is split into three parts: before the wind shift $\left(\mathrm{A}_{i}\right)$, during $\left(\mathrm{B}_{i}\right)$ and $\operatorname{after}\left(\mathrm{C}_{i}\right)$.

then selected requiring $U>5 \mathrm{~m} \mathrm{~s}^{-1}$ and an absolute value of the bulk Richardson number below $10^{-2}$. The last selection criterion was applied according to a suggestion by Andreas and Claffey (1995):

$$
\frac{\sum_{i=1}^{6}\left[U\left(z_{i}\right)-\left(u_{*} \kappa\right) \ln \left(z_{i} / z_{0}\right)\right]^{2}}{u_{*}^{2}} \leq \varepsilon,
$$

where $\varepsilon$ is an empirical constant determined from visual inspection of the observed wind speed profiles. Here it was set to 0.15 . Wind profiles that survived this filtering process were fitted (Eq. 1) using a log-linear least-squares regression technique, and $u_{*}$ and $z_{0}$ deduced from the regression coefficients. All of them yielded a correlation coefficient $\left(r^{2}\right)$ larger than 0.99 . The $80 \%$ confidence limits of each calculated $C_{\mathrm{DN} 10}$ value were determined following the statistical method proposed by Wilkinson (1984). The highest uncertainty bounds deduced from these confidence limits reached $\pm 14 \%$.

\section{Results}

The two erosion events depicted in Fig. 3 occurred in March (left panels) and October (right panels) 2013, during particularly constant wind direction conditions, which persisted after a wind shift of a few tens of degrees. Such constancy in wind direction, necessary for the following demonstration, is very rare. Combined with the strict selection procedure, only two cases were exploitable in this context. The $2 \mathrm{~m}$ wind speed, wind direction, profiled-derived $C_{\mathrm{DN} 10}$ values and aeolian snow mass flux recovered by the second-generation FlowCapt ${ }^{\mathrm{TM}}$ sensor are shown in Fig. 3. As the friction velocity is the actual dynamic quantity involved in aerodynamic entrainment of surface snow particles, it is also plotted on the graph. The two events are split into three parts, before the shift in wind direction $\left(\mathrm{A}_{i}\right)$, during $\left(\mathrm{B}_{i}\right)$ and $\operatorname{after}\left(\mathrm{C}_{i}\right)$. The occurrence of precipitation may affect the detection of erosion events because the FlowCapt ${ }^{\mathrm{TM}}$ sensor does not distinguish between eroded (saltating particles and/or suspended particles of snow) and precipitating snow particles. No vi- 
sual observations of precipitation from the nearby Dumont d'Urville station were available for the period concerned. Moreover, as Adélie Land is very prone to aeolian transport of snow, these observations, if performed, are limited by the inability to discriminate between actual precipitation and pure drifting snow. Here we used the operational analyses of the European Center for Medium-Range Weather Forecasts (horizontal resolution of $\sim 16 \mathrm{~km}$ ) to evaluate the occurrence of precipitation at our measurement site. We assumed that both events were pure erosion events after finding negligible precipitation rates for the fully continental grid point including D17.

At the beginning of Julian day (JD) 87 (part $\mathrm{A}_{1}$ ), the wind direction was around $140^{\circ}$, the friction velocity was above the erosion threshold with a related aeolian snow mass flux of $100 \mathrm{~g} \mathrm{~m}^{-2} \mathrm{~s}^{-1}$, and $C_{\mathrm{DN} 10}$ was near $1.5 \times 10^{-3}$. At the end of JD 87 (part $\mathrm{B}_{1}$ ), the wind rotated towards $160^{\circ}$ while $C_{\text {DN10 }}$ increased to nearly $3.3 \times 10^{-3}$, i.e. by $120 \%$, in response to a wind shift of only $20^{\circ}$. As assumed in Jackson and Carroll (1978), and Andreas and Claffey (1995), it is likely that as the wind turned, it was deflected from the mean sastrugi axis, thereby encountering a rougher surface. As a result, $C_{\mathrm{DN} 10}$ soared, reflecting the growing contribution of the sastrugi form drag to the vertical momentum flux at the surface and hence to the total surface drag. Within the same time frame, the measured aeolian snow mass flux fell by $\sim 30 \%$ from 365 to $260 \mathrm{~g} \mathrm{~m}^{-2} \mathrm{~s}^{-1}$, despite increasing friction velocity (wind speed) from 0.7 to 1.6 (18 to 24$) \mathrm{m} \mathrm{s}^{-1}$. Then, until the end of the event (part $\mathrm{C}_{1}$ ), the wind direction remained centred about $160^{\circ}$. From 03:30 to 06:30 UT on JD $88, C_{\mathrm{DN} 10}$ fell back to $1.5 \times 10^{-3}$ as high winds presumably streamlined the surface. In other words, $C_{\mathrm{DN} 10}$ was reduced by $\sim 50 \%$ in only $3 \mathrm{~h}$. As $C_{\mathrm{DN} 10}$ decreased, the aeolian snow mass flux again rose above $400 \mathrm{~g} \mathrm{~m}^{-2} \mathrm{~s}^{-1}$. The erosion event lasted through JD 90 when $u_{*}$ (wind speed) dropped to 0.7 (15) $\mathrm{m} \mathrm{s}^{-1}$, causing a significant decrease in the aeolian snow mass flux. After nearly $48 \mathrm{~h}$ of persistent erosive winds, $C_{\mathrm{DN} 10}$ was as low as $1.3 \times 10^{-3}$.

During the two days that preceded the second erosion event (part $A_{2}$ ), the wind direction was within $\pm 10^{\circ}$ of $150^{\circ}$, the friction velocity was generally not strong enough to erode the snow surface and $C_{\mathrm{DN} 10}$ was between $1.3-1.6 \times 10^{-3}$. $C_{\mathrm{DN} 10}$ and wind direction were strongly correlated during this period, with the lowest drag coefficients occurring for a wind direction of around $140^{\circ}$, suggesting that this was the sastrugi alignment before erosion started and the wind changed direction. Then, the same situation depicted in the left panels of Fig. 3 occurred again. At mid-JD 286 (part $\left.\mathrm{B}_{2}\right), u_{*}$ increased beyond the erosion threshold as the wind rotated from 150 to $180^{\circ}$. Consequently, $C_{\mathrm{DN} 10}$ increased to $1.9 \times 10^{-3}$. The aeolian snow mass flux dropped simultaneously from 320 to $55 \mathrm{~g} \mathrm{~m}^{-2} \mathrm{~s}^{-1}$ under increasing friction velocity. That is, for a $\sim 30 \%$ increase in $C_{\text {DN10 }}$ as the result of a wind deflection of $30^{\circ}$, the aeolian snow mass flux decreased by $\sim 80 \%$. Together with the first case of erosion, this illustrates how the form drag exerted by sastrugi can significantly affect snow erosion when the wind and sastrugi are not aligned (this effect is discussed later in the paper; see Sect. 4). Then (part $\mathrm{C}_{2}$ ), the wind direction remained roughly unchanged until erosion ceased. Again, the rise in aeolian snow mass flux coincided with a decrease in $C_{\mathrm{DN} 10}$. After nearly $3 \mathrm{~h}$ of winds above $20 \mathrm{~m} \mathrm{~s}^{-1}\left(u_{*}>0.9 \mathrm{~m} \mathrm{~s}^{-1}\right)$ from $180^{\circ}, C_{\text {DN10 }}$ fell from $1.9 \times 10^{-3}$ to $1.4 \times 10^{-3}$, i.e. decreased by $\sim 30 \%$.

In summary, for friction velocities (wind speeds) around 1 (20) $\mathrm{m} \mathrm{s}^{-1}$ and above, the sastrugi streamlining timescale can be as fast as $3 \mathrm{~h}$. For a wind flow initially aligned with the sastrugi, a deviation of $20-30^{\circ}$ from the streamlining direction has the potential to both increase $C_{\mathrm{DN} 10}$ by $30-120 \%$ and to significantly reduce (up to $80 \%$ ) the aeolian snow mass flux, even under increasing friction velocity.

\section{Discussion}

At Ice Station Weddell, Andreas and Claffey (1995) measured a decrease in $C_{\mathrm{DN} 10}$ of $20-30 \%$ in $12 \mathrm{~h}$ with considerably weaker winds $\left(<12 \mathrm{~m} \mathrm{~s}^{-1}\right)$ than those reported here. The observations reported in this paper show that this timescale can be 4 times faster for winds exceeding $20 \mathrm{~m} \mathrm{~s}^{-1}$ $\left(u_{*}>1 \mathrm{~m} \mathrm{~s}^{-1}\right)$ and the associated decrease in $C_{\mathrm{DN} 10}$ can reach $50 \%$. Andreas and Claffey (1995) also proposed generic

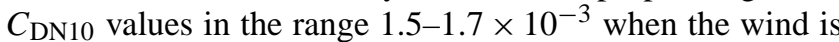
well aligned with the sastrugi, and around $2.5 \times 10^{-3}$ when the wind is at an angle of $20^{\circ}$ to the dominant orientation of the sastrugi. The present results differ slightly from these values: $C_{\mathrm{DN} 10}$ was more in the range $1.3-1.5 \times 10^{-3}$ for sastrugiparallel winds and could increase to nearly $3.3 \times 10^{-3}$ with a wind shift of similar amplitude. For a given erosion threshold, the quantity of windborne snow increases with friction velocity according to a power law (Mann et al., 2000). As sastrugi mainly form through snow erosion/deposition processes (Filhol and Sturm, 2015), it is likely that under the strong wind (shear) conditions in Adélie Land, rougher snow surfaces develop, which have a greater aerodynamic adjustment ability than at the less windy Ice Station Weddell.

During both erosion events, significant aeolian snow mass fluxes were measured for $2 \mathrm{~m}$ wind speeds $\left(u_{*}\right)$ of 10 (0.6) $\mathrm{m} \mathrm{s}^{-1}$ or above. As the wind (friction) velocity is likely to frequently exceed this threshold on the coastal slopes of Adélie Land, the sastrugi alignment process might be also frequently active, depending on the persistence of the wind. As suggested in Sect. 1, this mechanism is probably also strongly controlled by the properties of the snow surface that determine the threshold shear stress required for erosion to begin, rather than only the characteristics of the wind. Since the erosion flux is the integrated result of both the capacity of the wind to erode and carry snow and snow surface erodibility, the sastrugi streamlining timescale presumably mostly depends on this specific quantity. The implication is 
that the drag coefficient must be strongly related to other factors including the current wind orientation and the history of the wind's interactions with the snow surface as well as past timescales and past temperatures of the snowpack.

On the other hand, the sastrugi streamlining timescale also appears to control snow erosion in the form of feedback by fixing the time during which the sastrugi form drag mainly contributes to total surface drag. With friction velocities above the snow erosion threshold, increasing $u_{*}$ could be expected to result in an increase in erosion efficiency. However, in both cases the observations showed a significant decrease in the aeolian snow mass flux in phase with an increase in the drag coefficient (Fig. 3, parts B). By analogy with measurements made in a water flume (Wiberg and Nelson, 1992; Le Bouteiller and Venditti, 2015), it can be considered that the flow and turbulence in the sastrugi region are the result of interaction between flow separation and wake formation, which can lead to a local Reynolds shear stress peak corresponding to flow separation. Above the region of influence of the wake, named outer region, the flow has adjusted to increased roughness and exhibited a logarithmic profile, as shown by the relative continuous time series of $C_{\mathrm{DN} 10}$ and $u_{*}$ (Fig. 3), despite the strict selection procedure. Even if the shear stress of the outer flow $(\tau)$ is relatively easy to measure, it cannot be extrapolated to the snow bed. The averaged snow bed shear stress (also referred to as skin friction in the literature), which is the ultimate parameter for aeolian erosion ( $\mathrm{Li}$ and Shao, 2003), varies depending on its position along the sastrugi field. In absence of direct measurements, it is necessary to link outer shear stress, sastrugi geometry and skin friction to be able to estimate aeolian snow mass fluxes. This is quite important since the reduction of shear stress near the surface is crucial for limiting the growth of the mass flux (Groot Zwaaftink et al., 2014). For erodible forms in riverbeds such as ripples, Smith and McLean (1977) and later Wiberg and Nelson (1992) developed a method for partitioning the outer shear stress. These authors considered that the averaged bed shear stress is equal to the difference between the outer shear stress and the drag-related stress produced as the flow is forced around the bedform -i.e. in the present case, the form drag induced by the sastrugi. As mentioned above, an increasing form drag can be expected and hence a decrease in skin friction and in aeolian snow mass flux, when the wind direction gradually shifts away from the longitudinal axis of the sastrugi. Because $C_{\mathrm{DN} 10}$ reflects the contribution of the sastrugi form drag, knowing the drag coefficient is not sufficient to estimate skin friction. A better knowledge of skin friction over a sastrugi field is also needed to improve aeolian snow mass flux parameterizations in aeolian erosion models. The measurements made in the present study showed that a considerable decrease (even $80 \%$ ) of the aeolian snow mass flux can occur during the transitional regime during which the wind and sastrugi are not aligned (Fig. 3, parts B). But it should be also noted that, assuming a relative constancy in wind direction, the rapid aerodynamic adjustment of sastrugi (here $3 \mathrm{~h}$ ) will limit errors if the erosion event considered is strong and sufficiently long.

\section{Conclusions}

An experimental meteorological data set collected in coastal Adélie Land during austral winter 2013 was exploited to document surface turbulent fluxes of momentum and snow over an Antarctic sastrugi field. The main results of the analysis of two erosion events can be summarized as follows:

$-\mathrm{C}_{\mathrm{DN} 10}$ values are in the range of $1.3-1.5 \times 10^{-3}$ when the wind is well aligned with the sastrugi.

- As the wind shifts by only $20-30^{\circ}$ away from the streamlined direction, $\mathrm{C}_{\mathrm{DN} 10}$ increases (by $30-120 \%$ ) and the aeolian snow mass flux decreases (by 30-80\%), thereby reflecting the growing contribution of the sastrugi form drag to the total surface drag and its inhibiting effect on snow erosion.

- The timescale for the aerodynamic adjustment of sastrugi can be as low as three hours for friction velocities greater than $1 \mathrm{~m} \mathrm{~s}^{-1}$ and during strong drifting snow conditions.

- Because $C_{\mathrm{DN} 10}$ includes the contribution of the sastrugi form drag, knowing $C_{\mathrm{DN} 10}$ is not sufficient to estimate the erosion flux that results from drag partitioning at the surface.

These results support the existence of feedback mechanisms linking aeolian erosion and surface drag properties over (Antarctic) snow surfaces, as already demonstrated for erodible desert-like surfaces (Marticorena and Bergametti, 1995). In contrast with non-erodible roughness elements such as rocks or vegetation, these mechanisms involve the time needed for sastrugi to adjust to the main wind $(3 \mathrm{~h}$ in both erosion events), during which both the drag coefficient and the aeolian snow mass flux can be greatly modified. In comparison, Andreas and Claffey (1995) reported a longer timescale $(12 \mathrm{~h}$ ) for the sastrugi to realign with weaker winds. Because lighter winds are supposed to be associated with lower erosion fluxes, it is suggested that the sastrugi streamlining timescale most likely depends on the snow erosion flux.

Real-time observations of the distribution (size, abundance, orientation) of the sastrugi would further advance understanding of the physical processes involved in the development of sastrugi and enable better characterization of sastrugi aerodynamic adjustment timescales. In addition, having a more accurate representation of the distribution of sastrugi would make small-scale modelling in a wind tunnel possible, in which case it would be possible to realistically estimate shear stress partitioning. One possible way to monitor sastrugi would be to set up an automatic mini laser-scan. Such a 
device was developed in the framework of the MONISNOW (MONItoring SNOW in a changing climate) research project (Picard and Arnaud, LGGE, personal communication, 2016) and has been operating daily at Dome $\mathrm{C}$ in Antarctica since the beginning of 2015. These complementary approaches are vital to improve parameterization schemes for aeolian snow transport models and general drag parameterizations for weather, climate and earth system models.

Acknowledgements. This work would not have been possible without the financial and logistical support of the French Polar Institute IPEV (program CALVA-1013). The authors would like to thank all the on-site personnel in Dumont d'Urville and Cap Prud'homme for providing valuable help in the field, in particular Philippe Dordhain for electronic and technical support, as well as the two anonymous reviewers for their constructive remarks that helped to improve the manuscript considerably.

Edited by: X. Fettweis

\section{References}

Agosta, C., Favier, V., Genthon, C., Gallée, H., Krinner, G., Lenaerts, J. T. M., and van den Broeke, M. R.: A 40-year accumulation dataset for Adélie Land, Antarctica and its application for model validation, Clim. Dynam., 38, 75-86, 2012.

Amory, C., Trouvilliez, A., Gallée, H., Favier, V., Naaim-Bouvet, F., Genthon, C., Agosta, C., Piard, L., and Bellot, H.: Comparison between observed and simulated aeolian snow mass fluxes in Adélie Land, East Antarctica, The Cryosphere, 9, 1373-1383, doi:10.5194/tc-9-1373-2015, 2015.

Andreas, E. L.: Air-ice drag coefficients in the western weddell sea. 2. A model based on form drag and drifting snow, J. Geophys. Res., 100, 4833-4843, 1995.

Andreas, E. L. and Claffey, K. J.: Air-ice drag coefficients in the western weddell sea. 1. Values deduced from profile measurements, J. Geophys. Res., 100, 4821-4831, 1995.

Budd, W. F.: The drifting of non-uniform snow particles, in: Studies in Antarctic Meteorology, edited by: Rubin, M. J., Antarctic Research Series, Vol. 9, American Geophysical Union, 59-70, 1966.

Das, I., Bell, R. E., Scambos, T. A., Wolovick, M., Creyts, T. T., Studinger, M., Frearson, N., Nicolas, J. P., Lenaerts, J. T. M., and van den Broeke, M. R.: Influence of persistent wind scour on the surface mass balance of Antarctica, Nat. Geosci., 6, 367-371, 2013.

Filhol, S. and Sturm, M.: Snow bedforms: A review, new data and a formation model, J. Geophys. Res., 120, 1645-1669, doi:10.1002/2015JF003529, 2015.

Gallée, H., Trouvilliez, A., Agosta, C., Genthon, C., Favier, V., and Naaim-Bouvet, F.: Transport of Snow by the Wind: A Comparison Between Observations in Adélie Land, Antarctica, and Simulations Made with the Regional Climate Model MAR, Bound.Lay. Meteorol., 146, 133-147, 2013.

Groot Zwaaftink, C. D., Diebold, M., Horender, S., Overney, J., Lieberherr, G., Parlange, M., and Lehning, M.: Modelling smallscale drifting snow with a Lagrangian stochastic model based on large-eddy simulations, Bound.-Lay. Meteorol., 153, 117-139, doi:10.1007/s10546-014-9934-2, 2014.

Inoue, J.: Surface drag over the snow surface of the Antarctic Plateau. 1: factors controlling surface drag over the katabatic wind region, J. Geophys. Res., 94, 2207-2217, 1989.

Jackson, B. S. and Carroll, J. J.: Aerodynamic roughness as a function of wind direction over asymmetric surface elements, Bound.-Lay. Meteorol., 14, 323-330, 1978.

Joffre, S. M.: Momentum and heat transfers in the surface layer over a frozen sea, Bound.-Lay. Meteorol., 24, 211-229, 1982.

König-Langlo, G., King, J. C., and Pettré, P.: Climatology of the three coastal Antarctic stations Dumont d'Urville, Neumayer, and Halley, J. Geophys. Res., 103, 10935-10946, doi:10.1029/97JD00527, 1998.

Kotlyakov, V. M.: The Snow Cover of the Antarctic and its role in the Present-Day Glaciation of the Continent (Snezhni pokrov antarktidy i ego rol' v somvremennom oledenenii materika), Translated from Russian 1966, Israel Program for Scientific Translation, Jerusalem, 256 pp., 1961.

Le Bouteiller, C. and Venditti, J. G.: Sediment transport and shear stress partitioning in a vegetated flow, Water Resour. Res., 51, 2901-2922, doi:10.1002/2014WR015825, 2015.

Lettau, H. H.: Note on aerodynamic roughness-parameter estimation on the basis of roughness element description, J. Appl. Meteorol., 8, 828-832, 1969.

Li, L. and Pomeroy, J. W.: Estimates of Threshold Wind Speeds for Snow Transport Using Meteorological Data, J. Appl. Meleorol., 36, 205-213, 1997.

Li, A. and Shao, Y.: Numerical simulation of drag partition over rough surfaces, Bound.-Lay. Meteorol., 108, 317-342. 2003.

Long, D. G. and Drinkwater, M. R.: Azimuth variation in microwave scatterometer and radiometer data over Antarctica, T. Geosci. Remote Sens., 38, 1857-1870, 2000.

Mann, G. W., Anderson, P. S., and Mobbs, S. D.: Profile measurements of blowing snow at Halley, Antarctica, J. Geophys. Res., 105, 24491-24508, 2000.

Marticorena, B. and Bergametti, G.: Modeling the atmospheric dust cycle: 1. Design of a soil-derived dust emission scheme, J. Geophys. Res., 100, 16415-16430, 1995.

Mather, K. B.: Further observations on sastrugi, snow dunes and the pattern of surface winds in Antarctica, Polar Rec., 11, 158-171, 1962.

Mather, K. B.: The pattern of surface wind flow in Antarctica, Pure Appl. Geophys., 75, 332-354, 1969.

Mather, K. B. and Miller, G. S.: Wind drainage off the high plateau of Eastern Antarctica, Nature, 209, 281-284, 1966.

Mellor, M.: Blowing snow, CRREL MonographIII, A3c, Cold Regions Res. And Eng. Lab., Hanover, N.H., 1965.

Ôura, H., Ishida, T., Kobayashi, D., Kobayashi, S., and Yamada, T.: Studies on blowing snow: Part II. Physics of Snow and Ice: Int. Conf. on Low Temperature Science, Sapporo, Japan, Institute of Low Temperature Science, Hokkaido University, 1099-1117, 1967.

Parish, T. R. and Bromwich, D. H.: The surface wind field over the Antarctic ice sheet, Nature, 328, 51-54, 1987.

Parish, T. R. and Bromwich, D. H.: Reexamination of the nearsurface airflow over the Antarctic continent and implications on atmospheric circulations at high southern latitudes, Mon. Weather Rev., 135, 1961-1973, 2007. 
Parish, T. R., Pettré, P., and Wendler, G.: The influence of large scale forcing on the katabatic wind regime of Adélie Land, Antarctica, Meteor. Atmos. Phys., 51, 165-176, 1993.

Pomeroy, J. W., Gray, D. M., and Landine, P. G.: The prairie blowing snow model: Characteristics, validation, operation, J. Hydrol., 144, 165-192, 1993.

Raupach, M. R.: Drag and drag partition on rough surfaces, Bound.Lay. Meteorol., 60, 375-395, 1992.

Sato, T., Kimura, T., Ishimaru, T., and Maruyama, T.: Field test of a new snow-particle counter (SPC) system, Ann. Glaciol., 18, 149-154, 1993.

Schmidt, R. A.: Threshold wind-speeds and elastic impact in snow transport, J. Glaciol., 26-94, 453-467, 1980.

Shao, Y.: Physics and modelling of wind erosion, Springer Verlag, 2008.
Smith, J. D. and McLean, S. R.: Spatially averaged flow over a wavy surface, J. Geophys. Res., 82, 1735-1746, 1977.

Trouvilliez, A., Naaim-Bouvet, F., Genthon, C., Piard, L., Favier, V., Bellot, H., Agosta, C., Palerme, C., Amory, C., and Gallée, H.: A novel experimental study of aeolian snow transport in Adélie Land (Antarctica), Cold Reg. Sci. Technol., 108, 125-138, 2014.

Trouvilliez, A., Naaim-Bouvet, F., Bellot, H., Genthon, C., and Gallée, H.: Evaluation of FlowCapt acoustic sensor for snowdrift measurements, J. Atmos. Ocean. Technol., 32, 1630-1641, 2015.

Wiberg, P. L. and Nelson, J. M.: Unidirectional flow over asymmetric and symmetric ripples, J. Geophys. Res., 97, 12745-12761, 1992.

Wilkinson, R. H.: A method for evaluating statistical errors associated with logarithmic velocity profiles, Geo.-Mar. Lett., 3, 49-52, 1984. 